\title{
A Review of the In Vivo Evidence Investigating the Role of Nitrite Exposure from Processed Meat Consumption in the Development of Colorectal Cancer
}

\author{
William Crowe, Christopher T. Elliott and Brian D. Green * (1) \\ Institute of Global Food Security, School of Biological Sciences, Queens University Belfast, Belfast BT9 5DL, UK; \\ w.crowe@qub.ac.uk (W.C.); chris.elliott@qub.ac.uk (C.T.E.) \\ * Correspondence: b.green@qub.ac.uk; Tel.: +44-(0)28-90976541
}

Received: 14 August 2019; Accepted: 14 October 2019; Published: 5 November 2019

check for updates

\begin{abstract}
The World Cancer Research Fund (WCRF) 2007 stated that the consumption of processed meat is a convincing cause of colorectal cancer (CRC), and therefore, the public should avoid it entirely. Sodium nitrite has emerged as a putative candidate responsible for the CRC-inducing effects of processed meats. Sodium nitrite is purported to prevent the growth of Clostridium botulinum and other food-spoiling bacteria, but recent, contradictory peer-reviewed evidence has emerged, leading to media reports questioning the necessity of nitrite addition. To date, eleven preclinical studies have investigated the effect of consuming nitrite/nitrite-containing meat on the development of CRC, but the results do not provide an overall consensus. A sizable number of human clinical studies have investigated the relationship between processed meat consumption and CRC risk with widely varying results. The unique approach of the present literature review was to include analysis that limited the human studies to those involving only nitrite-containing meat. The majority of these studies reported that nitrite-containing processed meat was associated with increased CRC risk. Nitrite consumption can lead to the formation of N-nitroso compounds (NOC), some of which are carcinogenic. Therefore, this focused perspective based on the current body of evidence links the consumption of meat containing nitrites and CRC risk.
\end{abstract}

Keywords: nitrite; processed meat; colorectal cancer

\section{Introduction}

It has been reported that between $66 \%$ and $99 \%$ of Europeans consume processed meat, with the mean amount consumed per day ranging between 10 and $80 \mathrm{~g}$ per day [1]. Processed meats are defined as meats that have been modified through curing, fermentation, salting, smoking, or otherwise, for the purpose of improving shelf life and/or enhancing flavour. Red meat is a nutritionally important source of protein, providing all essential amino acids and minerals, such as iron, selenium, and zinc. In 2007, the World Cancer Research Fund (WCRF) stated that there is convincing evidence linking the consumption of red and processed meat with the development of colorectal cancer (CRC) [2]. The WCRF further stated that the public should limit their intake of red meat to below $500 \mathrm{~g}$ per week, and avoid processed meat entirely. A further update from the WCRF emphasized that no safe level of processed meat could confidently be attributed to a lack of risk [3]. The International Agency for Research on Cancer (IARC) stated that with every increase of $50 \mathrm{~g}$ of processed meat consumption per day, the risk of CRC rises by $18 \%$, whilst with every increase of $100 \mathrm{~g}$ of red meat consumed per day the risk of CRC rises by $17 \%$ [4]. Numerous meta-analyses have been conducted in this area, the majority of which have reported processed meat to be linked to CRC development [5-12]. Due to the narrow 
scope of a meta-analysis, no animal evidence is included in the synthesis, but animal studies are well controlled, so it is important to consider them in the balance of evidence.

Genetic risk factors are undoubtedly involved in CRC development; however, increasing evidence suggests a more minor role than previously thought. Studies mapping the geographical incidences of cancer have noted that incidences in immigrants begin to reflect that of the host nations' incidences within a single generation [13], indicating that environmental factors are the largest contributor to CRC development.

A number of components present in processed meat have been implicated as potential causes of CRC including heterocyclic amines (HCA), polycyclic hydrocarbons (PAH), nitrites, haem iron, and high fat. HCA and PAH are also present in other foodstuffs that are not associated with CRC, such as fish and poultry, and therefore, have been largely ruled out [14]. Nitrites have emerged as a leading candidate responsible for processed meats' association with CRC; however, it is possible that a combination of the constituents listed could coalesce to initiate the pathogenesis of CRC. Nitrites are an effective preservative that uniquely prevent the growth of clostridium botulinum. Nitrites also enhance the colour and flavour of processed meat. Nitrite consumption can lead to the endogenous formation of $\mathrm{N}$-nitroso compounds (NOC), some of which are carcinogenic [15].

The WCRF has extensively reviewed the existing research concerning the effect of processed meat consumption and CRC and their conclusions appear to be definitive. There is good reason to believe that a causal relationship exists; however, there is not consensus of opinion in the scientific literature. This review analyses the conflicting preclinical and clinical research investigating the role of processed meat consumption in the development of CRC. There is a specific focus on the relationship between nitrite-containing processed meat and CRC.

\subsection{Methods}

As shown in Figure 1, a literature search was conducted using 3 search engines: Pubmed, Scopus, and Web of Science. A combination of the following terms were searched: colorectal cancer, CRC, processed meat, sausage, bacon, nitrite, and $N$-nitroso compounds.
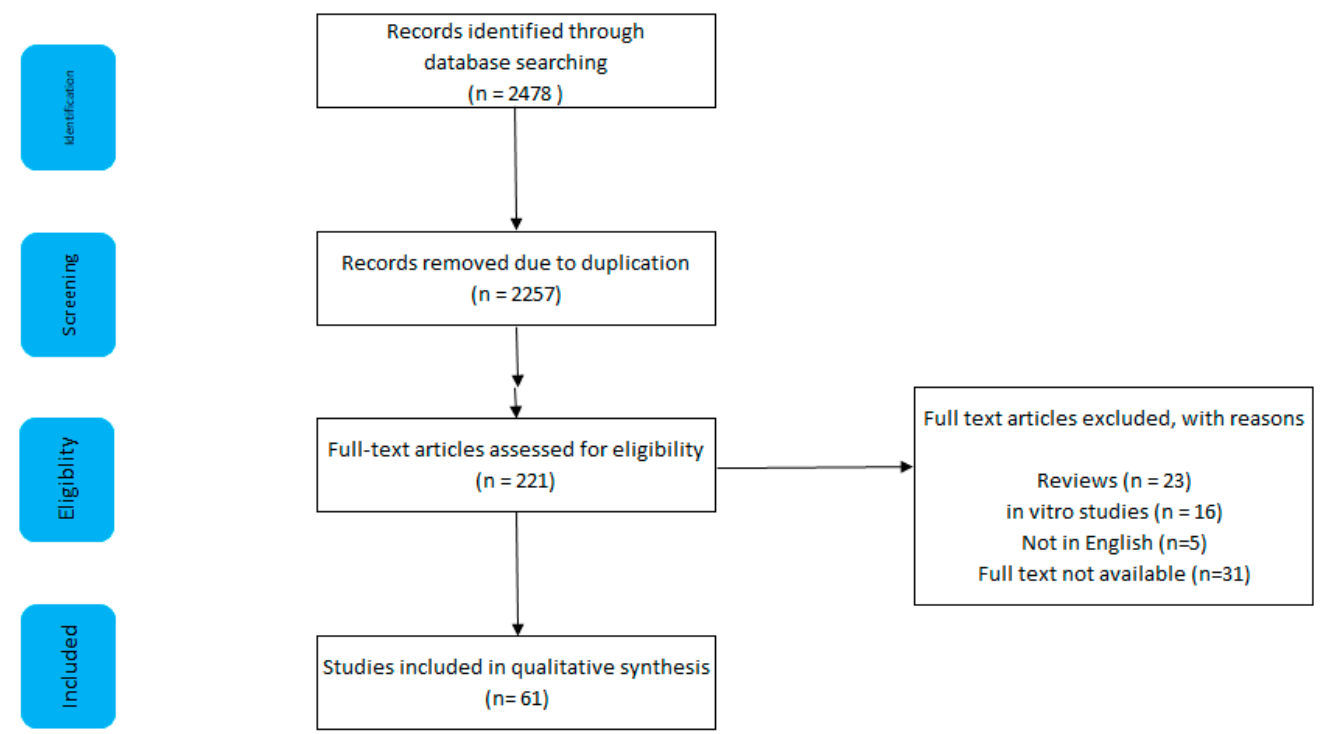

Figure 1. Search strategy and results, including reasons for exclusion.

\subsection{Inclusion and Exclusion}

Studies were included provided that they met the following criteria: full text was available, written in English, including single or multiple measures of colorectal cancer; that it was a human study that included a measurement of processed meat consumption. Reviews and technical reports were excluded. Studies that only utilised in vitro techniques were excluded. 


\subsection{Results}

The search yielded 2478 results, of which 61 were deemed to be appropriate. A total of 2257 articles were excluded owing to duplication; five articles were not in English; full text was not available for 31 articles; 23 reviews/technical reports/letters to editors were excluded; 16 studies used only in vitro techniques; 85 human studies did not measure processed meat consumption.

\section{Preclinical Evidence}

As shown in Table 1, eleven preclinical studies have investigated the effect of nitrite-containing processed meat consumption on CRC development. Eight studies employed Fischer rats, one employed Sprague Dawley rats, one employed $\mathrm{Apc}^{\mathrm{Min}}$ mice, and one used A/J mice and CF-1 mice.

Unfortunately, the Apc ${ }^{\text {Min }}$ study exposed animals to nitrite supplemented water, and therefore, did not supplement processed meat with nitrite. In nine of the studies, the development of CRC was confirmed by the occurrence of aberrant crypt foci (ACF) or mucin depleted foci (MDF). One study measured faecal levels of NOC and one measured total N-nitroso compounds, cytotoxicity, and thiobarbituric-acid-reactive substances.

Three of the eleven studies concluded that nitrite exposure did not increase the risk of CRC [16-18]. One found that hot dog did not increase the risk but $1.5 \mathrm{~g}$ sodium nitrite/L did [19]. Five studies concluded that nitrite exposure resulted in an increased risk of CRC [20-24]. Mirvish et al. 2003 reported that nitrite consumption increased NOC excretion but did not measure any CRC outcomes [25]. One study reported that nitrite ingestion elicited a protective effect on CRC development [26]. Those studies which found that nitrite-containing processed meat was causative for CRC, all exposed animals to a dietary amount of at least $50 \%$ processed meat. Although potentially achievable in the human diet, it seems unrealistic. Conversely, the only study which found processed meat to be protective for CRC provided a $60 \%$ meat diet for a period of 100 days. One explanation for the different outcome of this study is that the processed meat (bacon) group contained much higher $\mathrm{NaCl}$ levels than the control. This increases water intake and subsequently raises faecal moisture content. The intestinal dilution of nitrous compounds is one possibility for the reported findings.

Two studies that reported a causative relationship did not have adequate control groups to conclude that the findings were due to nitrite $[22,23]$. Furthermore, neither had a negative control, and were both are unable to conclude that processed meat increases the risk of CRC compared with a meat-free diet. Two studies reporting no effect used nitrite-containing water rather than nitrite in a food matrix $[16,23]$. In these studies, nitrite and haem iron were provided concomitantly, but not protein. The carcinogenic NOCs form most efficiently in the presence of high levels of nitrite, iron, and protein [27]. Therefore, studies which add nitrite alone or in the absence of either iron and protein, will not realise the full carcinogenic effect. The above two studies were also the only studies not to actually measure ACF and MDF.

The majority of studies investigating nitrite causation of CRC measured ACF and MDF as the primary outcomes. Adenomas typically take several months to manifest, whilst ACF and MDF develop in a matter of weeks. Therefore, ACF and MDF are used widely used, especially as there is a high concordance between the quantity of $\mathrm{ACF}$ and MDF and the development of adenomas. ACF is an early histopathological indicator of CRC, but it should be pointed out that not all ACF lesions lead to clinical CRC. These are easily identifiable pre-neoplastic lesions that are typically present on the mucosal surface. MDF are a subset of ACF, the primary difference being that mucous production is suppressed in MDF. Visual inspection of the colon remains the gold standard for confirming the determination of disease pathology. Although there are putative blood, urinary, and faecal biomarkers, none of them are as specific and sensitive as ACF and MDF [28,29]. 
Table 1. Characteristics of animal studies assessing colorectal cancer and nitrite consumption

\begin{tabular}{|c|c|c|c|c|c|}
\hline Author & Model & Intervention & Fat Content & Control & Outcome \\
\hline [17] Parnaud et al. 1998 & Fischer rat & $\begin{array}{c}30 \% \text { bacon (freeze dried), } 70 \% \text { AIN-76 for } \\
100 \text { days } \\
60 \% \text { bacon for } 30 \text { days }\end{array}$ & $7 \%, 14 \%, 28 \%$ & $\begin{array}{l}\text { AIN-76 formula with identical } \\
\text { protein and fat (Casein and lard } \\
\text { used to increase macros) }\end{array}$ & $\begin{array}{l}\uparrow \text { Fecal NOC level } \\
\text { No ACF were detected in the colon } \\
\text { of bacon-fed uninitiated rats. }\end{array}$ \\
\hline [26] Parnaud et al. 2000 & Fischer rat & $\begin{array}{c}30 \% \text { bacon (freeze dried), } 70 \% \text { AIN-76 for } \\
100 \text { days } \\
60 \% \text { bacon for } 100 \text { days }\end{array}$ & $\begin{array}{l}14 \% \\
28 \%\end{array}$ & $\begin{array}{l}\text { AIN } 76 \text { formula with identical } \\
\text { protein and fat (casein, olive oil } \\
\text { and lard used to increase macros) }\end{array}$ & $\begin{array}{c}\downarrow \mathrm{ACF} \text { by } 12 \% \text { in rats fed a diet with } \\
30 \% \text { bacon and by } 20 \% \text { in rats fed a } \\
\text { diet with } 60 \% \text { bacon. }\end{array}$ \\
\hline [25] Mirvish et al. 2003 & $\begin{array}{l}\text { Sprague- Dawley rats } \\
\text { and male mice of } \\
\text { various strains }\end{array}$ & $\begin{array}{l}18 \% \text { hot dog, } 82 \% \text { TD-01407 SP } 7 \text { days } \\
15 \% \text { beef. } 82 \% \text { TD-01407 SP } 7 \text { days }\end{array}$ & $26 \mathrm{~g} / 100 \mathrm{~g}$ & $\begin{array}{c}\text { TD-01407 } \\
\text { TD-98061 } \\
\text { AIN-76A diet } \\
\text { soy oil and casein added to } \\
\text { increase macros }\end{array}$ & $\begin{array}{l}\uparrow \text { Fecal NOC in hot dog and beef } \\
\text { fed compared with control. }\end{array}$ \\
\hline [20] Santarelli et al. 2010 & Fischer rat & $55 \%$ processed pork (moist), $45 \%$ AIN76 & $15 \mathrm{~g} / 100 \mathrm{~g}$ & AIN-76A & $\uparrow$ MDF in processed pork group. \\
\hline [21] Pierre et al. 2010 & Fischer 344 rats & $55 \%$ cured ham (freeze dried), $45 \%$ AIN76A & - & Ain-76A & $\begin{array}{l}\uparrow \mathrm{ACF} \text { and MDF in cured ham } \\
\text { fed group. }\end{array}$ \\
\hline [21] Santarelli et al. 2013 & Fischer rat & $\begin{array}{c}55 \% \text { processed meat (moist), } 40 \% \text { AIN76, } 5 \% \\
\text { safflower oil }\end{array}$ & $30 \%$ & AIN-76A with 5\% safflower & $\begin{array}{l}\uparrow \mathrm{MDF} \text { in hot dog fed group. } \\
\text { Addition of calcium carbonate } \\
\text { suppresses lesions. }\end{array}$ \\
\hline [16] Chenni et al. 2013 & F344 rats & $\begin{array}{c}\text { AIN-76 with sodium nitrite in drinking } \\
\text { water }(1 \mathrm{~g} / \mathrm{L}) \\
\text { nitrite }(0.17 \mathrm{~g} / \mathrm{L}) \text { and nitrate }(0.23 \mathrm{~g} / \mathrm{L})\end{array}$ & - & AIN-76A & No change. \\
\hline [22] Pierre et al. 2013 & Fischer 344 rats & $\begin{array}{c}55 \mathrm{~g} \text { (moist weight) experimental cured meat, } \\
45 \mathrm{~g} \text { AIN76 } 100 \text { days }\end{array}$ & $15 \%$ & AIN-76A & $\begin{array}{l}\uparrow \text { MDF in cured meat fed group, } \\
\text { compared with vitamin E and } \\
\text { calcium supplemented groups. }\end{array}$ \\
\hline [18] Bastide et al. 2015 & $\begin{array}{l}\text { F344 ratsC57BL/6J } \\
\text { ApcMin/+ } \\
\text { miceApc+/+ mice }\end{array}$ & $\begin{array}{c}\left(0.17 \mathrm{~g} / \mathrm{L} \text { of } \mathrm{NaNO}_{2} \text { and } 0.23 \mathrm{~g} / \mathrm{L} \text { of } \mathrm{NaNO}_{3}\right) \\
\text { added to water } \\
\text { AIN-76A with } 2.5 \% \text { haemoglobin }\end{array}$ & - & AIN-76A & $\begin{array}{l}\uparrow \mathrm{MDF} \text { in heme iron fed group. } \\
\text { No change in nitrite fed group. }\end{array}$ \\
\hline [19] Zhou et al. 2015 & $\mathrm{~A} / \mathrm{J}$ mice $\mathrm{CF}-1$ mice & $\begin{array}{c}0.5 \text { or } 1.0 \mathrm{~g} \mathrm{NaNO}_{2} / \mathrm{L} \\
0,1.0,1.25, \text { or } 1.5 \mathrm{~g} \mathrm{NaNO}_{2} / \mathrm{L} \\
18 \% \text { hot dog }\end{array}$ & - & AIN93G & $\begin{array}{l}\text { No change following hot dog } \\
\text { ingestion. } \uparrow \mathrm{ACF} \text { in } 1.5 \mathrm{~g} \text { compared } \\
\text { with untreated }\end{array}$ \\
\hline [23] Bastide et al. 2017 & Fischer 344 rats & $\begin{array}{c}50 \mathrm{~g} \text { cooked, cured meat, } 50 \mathrm{~g} \text { AIN76 } \\
100 \text { days } \\
\text { vs polyphenol rich diet }\end{array}$ & - & Ain-76A & $\uparrow$ MDF in cured meat fed group. \\
\hline
\end{tabular}

$\uparrow$ increased; $\downarrow$ decreased; ACF Aberrant crypt foci; CRC colorectal cancer; NOC N-nitroso compound level; MDF mucin depleted foci. 
In summary, the existing preclinical research investigating the effect of nitrite exposure on CRC development is conflicting and methodological inconsistencies are apparent. Furthermore, the lack of a dose-response study is a major deficiency. The heterogeneous nature of chemical-induced cancer in animal models can be problematic, due to the unpredictability of the location and timing of cancer development [30]. Despite the variability that ensues, the majority of existing studies have used chemically induced models. Future studies should investigate models spontaneously developing CRC, such as the Apc ${ }^{\mathrm{Min}}$ mouse. This is a murine model that is susceptible to colorectal adenomas, in which there is a deletion of the APC gene. It is similar to the human hereditary condition, familial adenomatous polyposis (FAP). The use of in vivo models with similar pathogeneses to human conditions will increase the ability to extrapolate the findings.

Differences in physiological processes exist between humans and murine models, preventing direct extrapolation of findings. For example, the microflora of humans and rats differ and given that bacteria can increase the formation of nitrosamines [31]. Such differences may have a considerable effect on the association between nitrite consumption and CRC development. It is, therefore, imperative to give greater credence to human studies.

\section{Clinical Evidence}

A large number of studies of differing designs have investigated the relationship between human processed meat consumption and CRC. Table 2; Table 3, respectively, describe all prospective studies and case-control studies conducted thus far. Supplementary Tables S1 and S2 include more information about the studies presented in Tables 2 and 3. Of the 49 human studies identified, 23 found that processed meat consumption was linked with CRC [32-54], 25 found no link [55-79], and one study found processed meat to be protective for CRC [80]. It is, therefore, difficult to draw any definitive conclusions from these studies. 
Table 2. Characteristics of prospective human studies assessing colorectal cancer and processed meat consumption

\begin{tabular}{|c|c|c|c|c|c|}
\hline Author & $\begin{array}{l}\text { Sample } \\
\text { Size }\end{array}$ & $\begin{array}{c}\text { Colorectal } \\
\text { Cancer Cases }\end{array}$ & $\begin{array}{l}\text { Description of } \\
\text { Processed Meat }\end{array}$ & Relative Risk (CI) & Findings \\
\hline [32] Oba et al. 2005 & 31,552 & 213 & Processed meat & $1.98(1.24-3.16) \odot^{\top} 0.85(0.50-1.43)$ 우 & Significantly $\uparrow$ risk of CRC in $0^{\top}$ not $q$ \\
\hline [33] Goldbohm et al. 1994 & 3123 & 393 & Processed meat & $1.72(1.03-2.87)$ & Significantly $\uparrow$ risk of CRC \\
\hline [44] Parr et al. 2013 & 84,210 & 674 & Processed meat & $1.54(1.08-2.19)$ & Significantly $\uparrow$ risk of CRC \\
\hline [48] Wu et al. 2006 & 14,032 & $581 \ddagger$ & Processed meat & $1.52(1.12-2.08)$ & Significantly $\uparrow$ risk of CRC \\
\hline [55] Bostick et al. 1994 & 35,215 & $212^{\top}$ & Processed meat & $1.51(0.72-3.17)$ & No significant risk of CRC \\
\hline [49] English et al. 2004 & 37,112 & 451 & Processed meat & $1.50(1.1-2.0)$ & Significantly $\uparrow$ risk of CRC \\
\hline [50] Norat et al. 2005 & 478,040 & 1329 & Processed meat & $1.42(1.09-1.86)$ & Significantly $\uparrow$ risk of CRC \\
\hline [56] Takachi et al. 2011 & 98,514 & 1145 & Processed meat & $1.27(0.95-1.71) \mathrm{or}^{\top} 1.19(0.82-1.74)$ 우 & No significant risk of $\mathrm{CRC}$ \\
\hline [51] Willet et al. 1990 & 88,751 & 150 & Processed meat & $1.21(0.53-2.72)$ & Significantly $\uparrow$ risk of $C R C$ in the 3 rd quintile but not the 4 th \\
\hline [67] Pietinen et al. 1999 & 27,111 & 185 & Processed meat & $1.20(0.7-1.8)$ & No significant risk of CRC \\
\hline [52] Cross et al. 2007 & 494,036 & 5107 & Processed meat & $1.20(1.09-1.32)$ & Significantly $\uparrow$ risk of CRC \\
\hline [46] Bradbury et al. 2019 & 468,910 & 2576 & Processed meat & $1.19(1.01-1.41)$ & Significantly $\uparrow$ risk of CRC \\
\hline [73] Giovannucci et al. 1994 & 47,949 & 205 & Processed meat & $1.16(0.44-3.04)$ & No significant risk of CRC \\
\hline [47] Cross et al. 2010 & 300,948 & 2719 & Processed meat & $1.16(1.01-1.32)$ & Significantly $\uparrow$ risk of $C R C$ \\
\hline [74] Chao et al. 2005 & 148,610 & 1197 & Processed meat & $1.13(0.91-1.41)$ & No significant risk of CRC \\
\hline [75] Lee et al. 2009 & 74,942 & 394 & Salted meat & $1.10(0.8-1.4)$ & No significant risk of CRC \\
\hline [76] Larsson et al. 2005 & 61,433 & $234 \ddagger 155 \ddagger$ & Processed meat & $1.07(0.85-1.33)$ & No significant risk of CRC \\
\hline [77] Ollberding et al. 2012 & 215,000 & 3404 & Processed meat & $1.06(0.94-1.19)$ & No significant risk of CRC \\
\hline [78] Egeberg et al. 2013 & 53,988 & 914 & Processed meat & $1.02(0.78-1.34)$ & No significant risk of CRC \\
\hline [79] Flood et al. 2002 & 45,496 & 487 & Processed meat & $0.97(0.73-1.28)$ & No significant risk of $C R C$ \\
\hline [57] Sato et al. 2006 & 47,605 & 358 & Ham or sausage & $0.91(0.61-1.35)$ & No significant risk of $C R C$ \\
\hline [58] Lin et al. 2004 & 37,547 & 202 & Processed meat & $0.85(0.53-1.35)$ & No significant risk of CRC \\
\hline [59] Knekt et al. 1999 & 9985 & 73 & Nitrite & $0.74(0.34-1.63)$ & No significant risk of CRC \\
\hline
\end{tabular}

$\mathrm{o}^{\top} \mathrm{male}$; female $\uparrow$ increased; $¥$ Proximal colon; $\ddagger$ distal colon; CRC colorectal cancer. Where the authors did not provide the relative risks for males and females combined, we have provided the gender specific relative risks. Relative risk values reflect those in the highest consumption group vs those in the lowest consumption group. All relative risk values are adjusted, more details are provided in Supplementary Table S1. 
Table 3. Characteristics of case control human studies assessing colorectal cancer and processed meat consumption

\begin{tabular}{|c|c|c|c|c|c|}
\hline Author & Cases $(n=)$ & Controls $(n=)$ & Description of Processed Meat & Relative Risk (CI) & Findings \\
\hline [53] Lohsoonthorn et al. 1995 & 279 & 279 & Bacon & $12.49(1.68-269.1)$ & Significantly $\uparrow$ bacon consumption in cases group \\
\hline [54] De Stefani et al. 2012 & 321 & 844 & Processed meat & $3.53(1.93-6.46) 2.01(1.07-3.76)$ & Significantly $\uparrow$ risk of CRC \\
\hline [34] Tajima and Tomina 1985 & 93 & 186 & Ham and sausage & 2.87 & Significantly $\uparrow$ risk of CRC \\
\hline [35] Levi et al. 2004 & 323 & 1271 & Processed meat & $2.53(1.50-4.27)$ & Significantly $\uparrow$ risk of CRC \\
\hline [36] Haenszel et al. 1973 & 179 & 357 & Sausage and other processed pork & $2.30 \mathrm{G}_{1.77 \phi 2.7 \neq}$ & Significantly $\uparrow$ risk of CRC \\
\hline [37] Young and Wolf 1988 & $152 \ddagger 201 \ddagger$ & 618 & Processed lunch meat & $1.85(1.33-2.58)$ & Significantly $\uparrow$ risk of CRC \\
\hline [38] Bidoli et al. 1992 & $123 ¥ 125 \stackrel{+}{\top}$ & 699 & Salami and sausages & $1.8 ¥ 1.9 \overline{\mathrm{T}}$ & Sig $\uparrow ¥$ but not $\overline{\mathbf{T}}$ \\
\hline [39] Navarro et al. 2003 & 287 & 566 & Cold cuts and sausages & $1.64(1.16-2.32)$ & Significantly $\uparrow$ risk of CRC \\
\hline [40] Rosato et al. 2013 & 329 & 1361 & Processed meat & $1.56(1.11-2.20)$ & Significantly $\uparrow$ risk of CRC \\
\hline [41] Hu et al. 2008 & 3174 & 5039 & Processed meats & $1.50(1.2-1.8)$ & Significantly $\uparrow$ risk of CRC \\
\hline [60] Williams et al. 2010 & 945 & 959 & Processed meat & $1.36(0.80-1.68)$ F $1.02(0.38-1.96)^{t}$ & No significant risk of CRC \\
\hline [61] Benito et al. 1990 & 286 & 498 & Processed meat & 1.36 & No significant risk of CRC \\
\hline [42] De Verdier et al. 1991 & 559 & 505 & Sausage & $1.30(0.8-1.9) ¥ 1.7(1.1-2.8) \overline{\mathrm{T}}$ & Significantly $\uparrow$ risk of CRC \\
\hline [62] Dales et al. 1978 & 99 & 280 & Nitrite treated meats & 1.22 & No significant risk of CRC \\
\hline [63] Joshi et al. 2015 & 3350 & 3504 & Processed meats & $1.20(1.0-1.4)$ & No significant risk of CRC \\
\hline [64] Balder et al. 2006 & 1535 & 4371 & Processed meats & $1.18(0.84-1.64)$ & No significant risk of CRC \\
\hline [65] Murtaugh et al. 2003 & 952 & 1205 & Processed meat & $1.18(0.87-1.61) \risingdotseq 1.23(0.84-1.81) 0^{7}$ & No significant risk of $\mathrm{CRC}$ \\
\hline [66] Kimura et al. 2007 & 782 & 793 & Processed meats & $1.15(0.83-1.60)$ & No significant risk of CRC \\
\hline [68] Nothlings et al. 2009 & 1009 & 1522 & Processed meat & $1.08(0.89-1.39)$ & No significant risk of $C R C$ \\
\hline [69] Steinmetz and Potter 1993 & 220 & 438 & Processed meat & $1.03(0.55-1.95) 0^{\mho^{\top}} 0.77(0.35-1.68)$ 우 & No significant risk of CRC \\
\hline [70] Franceschi et al. 1997 & 1225 & 4154 & Processed meat & $1.02(0.89-1.24)$ & No significant risk of CRC \\
\hline [71] Centozone 2009 & 119 & 119 & Processed meat & 1.01 & No significant risk of CRC \\
\hline [72] Tiemersma et al. 2002 & 102 & 537 & Sausage & $0.90(0.6-1.3)$ & No significant risk of $\mathrm{CRC}$ \\
\hline [43] Macquart-Moulin 1986 & 399 & 399 & Charcuterie & 0.89 & Significantly $\uparrow$ risk of CRC \\
\hline [80] Iscovich et al. 1992 & 110 & 220 & Processed meat & $0.43(0.21-0.89)$ & Significantly $\downarrow$ risk of CRC \\
\hline [45] Nowell et al. 2002 & 157 & 380 & Sausage and bacon & - & Significantly $\uparrow$ bacon consumption in cases group \\
\hline
\end{tabular}

$\uparrow$ increased; $\downarrow$ decreased $¥$ Proximal colon; $\ddagger$ distal colon; $\sigma^{\top}$ male; ffemale; $¥$ colon; $\overline{\mathbf{T}}$ rectal; $\mathrm{F}$ caucasion; $\forall$ African American; CRC colorectal cancer. Where the authors did not provide the relative risks for males and females combined, we have provided the gender specific relative risks. Relative risk values reflect those in the highest consumption group vs those in the lowest consumption group. All relative risk values are adjusted, with the exception of Iscovich et al. and Nowell et al. more details of adjustments are provided in Supplementary Table S2. 
Although an equal number of studies prove/disprove the link between processed meat and CRC, those studies which found a relationship generally involved more participants; this explains why numerous meta-analyses have concluded that processed meat is a risk factor for CRC [5-7]. One study reported no association between processed meat consumption and CRC in men $(n=241)$, but reported a beneficial association between processed meat and CRC in women $(n=197)$ [69]. Two further prospective studies found that processed meat consumption was associated with CRC in men but not in women $[37,59]$. These findings were supported by three further studies $(n=119,260)$ indicating no effect of processed meat in female cases and controls [32,55,79]. A study of almost 48,000 American men reported that the association between processed meat consumption and CRC did not reach significance $(p=0.06)[73]$.

\section{Studies Focusing on Nitrite-Containing Meat and CRC}

Of the human studies discussed above, 17 studies investigated nitrite-containing processed meats (Table 4). Five studies found nitrite-containing processed meats to have no effect on CRC [43,56,57,59,62] and one study found nitrite-containing processed meat was protective [80]. In contrast, a total of 11 studies found that nitrite-containing processed meat increases the risk of CRC [34-39,42,45,48,49,53]. This indicates that the proposed causal relationship between processed meat is potentially skewed by the intake of nitrite-containing processed meats.

Of the prospective studies discussed $(n=5)$, three used the International Classification of Diseases criteria to confirm that the participant met the conditions of a positive diagnosis of CRC [49,57,59]; two studies did not specify which criteria they used. Wu et al. [48] consulted the patients' medical records. Takachi et al. [56] conducted a linkage study, where the researchers had access to a local cancer registry. Of the case-control studies $(n=12)$, ten studies recruited participants that had histologically confirmed adenocarcinoma; only one stated that the International Classification of Diseases criteria was applied to their study population [80]. Dales et al. [62] recruited hospitalized CRC patients, whilst Young and Wolf [37] recruited participants from the Wisconsin Cancer Reporting System.

All studies used a food frequency questionnaire (FFQ) to capture processed meat consumption in their respective cohorts; only two of the studies set out with the intention of investigating the role of nitrite in CRC development $[59,62]$ and both of these found no relationship. No study considered the concomitant consumption of haem proteins, and only one study considered the effect of nitrosamine exposure [59] levels; however, no study directly measured that. The FFQs varied in design and detail. Three studies recorded information on portion size [43,45,57], and the remainder did not. Researchers invited participants to describe their consumption habits in a number of ways, Dales et al. [62] included eight different frequencies, ranging from "never" to "at least once a day." Four studies provided their participants with six frequencies to choose from $[34,37,48,80]$. Two studies used five categories of frequency [42,57], Lohsoonthorn et al. [53] used four categories; the remainder of the studies did not specify how many categories were available $(n=10)$. Only one study described their FFQ as validated [39]. It has been shown that illness substantially effects dietary intake, and it is, therefore, crucial that all studies investigating the causative effect of habitual dietary pattern, consider the period prior to illness. Of the studies that recruited participants with existing CRC $(n=12)$, seven studies stated that participants were instructed to record dietary information on periods prior to illness. These periods ranged from weekly to over the course of the participant's lifetime. 
Table 4. Characteristics of prospective and case control human studies assessing colorectal cancer and nitrite containing meat

\begin{tabular}{|c|c|c|c|c|c|}
\hline Author & Sample size & $\begin{array}{l}\text { Colorectal } \\
\text { Cancer Cases }\end{array}$ & Description of Processed Meat & Relative Risk (CI) & Findings \\
\hline [48] Wu et al. 2006 & 14,032 & $581 \ddagger$ & Sausage, salami, bologna & $1.52(1.12-2.08)$ & Significantly $\uparrow$ risk of CRC \\
\hline [49] English et al. 2004 & 37,112 & 284 & $\begin{array}{l}\text { Salami, continental sausages, } \\
\text { sausages or frankfurters, bacon, ham }\end{array}$ & $1.50(1.1-2.0)$ & Significantly $\uparrow$ risk of CRC \\
\hline [56] Takachi et al. 2011 & 98,514 & 1145 & Processed meat & $1.27(0.95,1.71) o^{\top} 1.19(0.82,1.74)$ † & No significant risk of $C R C$ \\
\hline [57] Sato et al. 2006 & 47,605 & 358 & Ham or sausage & $0.91(0.61-1.35)$ & No significant risk of CRC \\
\hline [59] Knekt et al. 1999 & 9985 & 73 & Nitrite & $0.74(0.34-1.63)$ & No significant risk of CRC \\
\hline Author & Cases $(n=)$ & Controls $(n=)$ & Description of Processed Meat & Relative Risk (CI) & Findings \\
\hline [53] Lohsoonthorn et al. 1995 & 279 & 279 & Bacon & $12.49(1.68-269.1)$ & Significantly $\uparrow$ bacon consumption in cases group \\
\hline [34] Tajima and Tomina 1985 & 93 & 186 & Ham and sausage & 2.87 & Significantly $\uparrow$ risk of CRC \\
\hline [36] Haenszel et al. 1973 & 179 & 357 & Sausage and other processed pork & $2.3 \mathrm{G}_{1.77 \phi 2.7 \neq}$ & Significantly $\uparrow$ risk of CRC \\
\hline [35] Levi et al. 2004 & 323 & 1271 & Ham salami sausage & $2.53(1.50-4.27)$ & Significantly $\uparrow$ risk of CRC \\
\hline [38] Bidoli et al. 1992 & $123 ¥ 125 \overline{\mathrm{T}}$ & 699 & Salami and sausages & $1.8 \not 1.9 \overline{\mathrm{T}}$ & Sig $\uparrow ¥$ but not $\overline{\mathrm{T}}$ \\
\hline [37] Young and Wolf 1988 & $152 \ddagger 201 \ddagger$ & 618 & Processed lunch meat & $1.85(1.33-2.58)$ & Significantly $\uparrow$ risk of CRC \\
\hline [42] De Verdier et al. 1991 & 559 & 505 & Bacon & $1.3(0.8-1.9) ¥ 1.7(1.1-2.8) \overline{\mathrm{T}}$ & Sig $\uparrow ¥$ but not $\overline{\mathbf{T}}$ \\
\hline [39] Navarro et al. 2003 & 287 & 566 & Cold cuts and sausages & $1.64(1.16-2.32)$ & Significantly $\uparrow$ risk of CRC \\
\hline [62] Dales et al. 1978 & 99 & 280 & Nitrite treated meats & 1.22 & No significant risk of CRC \\
\hline [43] Macquart-Moulin 1986 & 399 & 399 & Charcuterie & 0.89 & No significant risk of CRC \\
\hline [80] Iscovich et al. 1992 & 110 & 220 & Delicatessen meat & $0.43(0.21-0.89)$ & Significantly $\downarrow$ risk of CRC \\
\hline [45] Nowell et al. 2002 & 157 & 380 & Sausage and bacon & - & Significantly $\uparrow$ bacon consumption in cases group \\
\hline
\end{tabular}

$\uparrow$ increased; $\downarrow$ decreased; $¥$ Proximal colon; $\ddagger$ distal colon; CRC colorectal cancer, $¥$ colon, $\overline{\mathbf{T}}$ rectum, ơ male; ofemale; $\mathcal{G}_{\text {Hawaiian; } \phi} \phi$ Issei; $\neq$ Nisei. Where the authors did not provide the relative risks for males and females combined, we have provided the gender specific relative risks. Relative risk values reflect those in the highest consumption group vs those in the lowest consumption group. All relative risk values are adjusted, with the exception of Iscovich et al. and Nowell et al. more details of adjustments are provided in Supplementary Tables S1 and S2. 
The above analysis of prior studies clearly indicates that there is a need for methodical studies which specifically investigate nitrite exposure, and which control for confounding factors, such as haem, and saturated fat intake. As a pre-requisite, a well-designed, validated FFQ focusing on processed meat must include portion size. An early report concluded that although processed meat consumption was linked to CRC development [36], nitrite was not responsible. This conclusion was based on the finding that meat with no nitrite had a higher relative risk than meat with nitrite [36]. The authors postulated that meat consumption was acting as a surrogate measure of saturated fat consumption, and that in fact, saturated fat intake could be responsible for the positive association [36]. Further investigation found that the frequency of consumption of nitrite-containing foods and high fat containing foods were not different between cases or controls [62]. This hypothesis is disputed by a study that found controlling for meat intake substantially decreased the association between fat intake and CRC development, suggesting that meat intake was responsible for the relationship [81].

Positive relationships between CRC and the consumption of salami [38], sausages [39], ham [34], and bacon [45] have been reported, although Sato et al. [57] found no relationship between CRC and sausage or ham intake. The content of a sausage differs greatly depending on the location it is being manufactured in. Sausages made in continental Europe tend to contain sodium nitrite, whilst British/Irish sausages do not. As the aforementioned studies that measured sausage intake were conducted in Argentina and Japan, respectively, it is difficult to determine the proportion of nitrite-containing sausages that the populations actually consumed.

In a prospective study of 9985 participants, it was reported that $N$-nitrosodimethylamine consumption was positively related to CRC development; when locating the origin of the $\mathrm{N}$-nitrosodimethylamine, there was a strong significant association between intake of smoked and salted fish and risk of CRC; however, the association between intake of cured meat and sausages with CRC was not significant [59]. A case-control study found that CRC patients were more likely to consume processed lunchmeat at various stages of their life compared with controls, and furthermore, it was speculated that additives such as nitrites may be responsible for this association [37]. Pierre et al. (2013) [22] conducted the only human intervention study in this area. Seventeen males were asked to abstain from meat and antioxidants for a 7-day control period, following which they consumed $180 \mathrm{~g}$ of ham per day for 4 days; after a washout period, the same participants consumed $180 \mathrm{~g}$ of tocopherol enriched ham a day for 4 days, and finally, $180 \mathrm{~g}$ of ham and $500 \mathrm{mg}$ of calcium per day. During the ham-only period, participants had significantly higher faecal levels of apparent total N-nitroso compounds (ATNC) and thiobarbituric acid reactive substances (TBARS) than during the control periods. The addition of calcium to the diet mitigated this rise. There was no change in the faecal water cytotoxicity or 1,4-Dihydroxynonane mercapturic acid (DHN-MA) following any treatment. None of the markers measured in that study are validated markers of colorectal cancer; however, they are the best available without imaging or visualising the colon. The existing human evidence indicates that nitrites, through their exogenous and endogenous conversion to NOCs, are an important contributing factor in the proposed causal link between processed meat consumption and CRC.

\section{Potential Mechanisms}

Up to $75 \%$ of NOC exposure can be attributed to endogenous production [82]. NOCs are formed following the ingestion of nitrite. The mechanism responsible for this is the electron exchange reaction involving amines and nitrogen oxides; this occurs most efficiently when at low $\mathrm{pH}$ [83]. NOCs are also encountered from exogenous sources, such as cigarette smoking and the diet. Nitrosamines are also exogenously produced, commonly occurring in foods such as cheese, fish, beer, and water. Common forms of exogenous derived nitrosamines are $N$-nitrosodimethyamine (NDMA); $N$-nitrosodiethylamine (NDEA); Nnitrosodibutylamine (NDBA); and $N$-nitrosopiperidine (NPIP). Not all of these compounds are carcinogens but some have been classified as probable by IARC [84].

The enzymatic incorporation of a hydroxyl group to $N$-nitrosamines catalysed by cytochrome P450 2E1 (CYP2E1) yields diazomethane, and ultimately, DNA-reactive methyl carbocation [85]. 
This involves the formation of methylated DNA adducts, by the addition of an alkyl group to oxygen within DNA bases, which leads to the production of two mutagenic nucleobases, $O^{6}$-methylguanine and $\mathrm{O}^{4}$-methylthymine [86]. The relationship between CYP2E1 and NOC metabolism is so profound that it has been reported that depletion of CYP2E1 confers resistance to smoking-induced lung cancer [87]. Haem centres can reduce nitrite to nitric oxide (NO), and depending on substrate availability, nitrosation can then occur. It has been shown that the nitrosation of amines can lead to the production of diazoacetate and ultimately $\mathrm{O}^{6}$-carboxymethyl-2'-deoxy-guanosine, which is a further NOC DNA adduct [88].

Multiple nutrients have been shown to prevent the formation of NOCs, including vitamin C, vitamin E, and chlorophyll. It is well established that vegetables contain significant amounts of nitrates which can be reduced by bacteria during mastication to form nitrite, and this nitrite enters the stomach for nitrosation. However, as vegetables do not contain haem, instead containing antioxidants such as vitamin C, vitamin E, and chlorophyll, the nitrite derived from vegetables does not pose the same mutagenic risk as processed meat.

\section{Discussion}

CRC is a somatic genetic disease and its onset is influenced by both the colonic environment and the patient's genetic background. Increased CRC risk is evident in populations of particular dietary patterns. Studies that have focused on singular foodstuffs or nutrients have frequently yielded inconclusive findings, indicating that the risk of CRC is altered depending on dietary pattern rather than simply the consumption of a particular food. Thus, by far the majority of studies have not considered the cumulative effects of multiple risk factors, including increased abdominal adipose tissue, cigarette smoking, physical inactivity, alcohol intake, consumption of saturated fats, and low fibre consumption. The long-term, habitual consumption of processed meat is likely to be another contributing factor $[89,90]$. It is evident from the pre-clinical studies that haem is a promotor of CRC development; however, it is unclear from the human evidence if it is simply a confounding factor or an important contributor. The majority of human studies conducted have included multivariate analysis to control for confounding factors; however, too frequently the researchers rely on self-reported data. It is clear from the proposed mechanism that nitrite requires other nutrients to be present to produce carcinogenic compounds. Future research should take a holistic dietary approach when analysing exposure data.

The majority of nitrates ingested in the diet come from vegetable consumption. As previously stated, nitrates are reduced during mastication to form nitrite; the acidic environment of the stomach encourages further reduction to create NO and S-nitrosothiols. In conflict with the conclusions of this review, these by-products of nitrites can elicit beneficial health effects; acidified nitrite can enhance the stomach's antimicrobial activity. Specifically, acidified nitrite has been shown to prevent the growth of Salmonella enteriridis, Salmonella typhumurium, Yersinia enterocolitica, Shigella sonnei, and Escherichia coli (DYK) [91]. NO has also been shown to be a potent vasodilator, and S-nitrosothiols are known to modulate platelet function. These two functions coalesce to improve cardiovascular function, through a lowering of blood pressure. Oxides of nitrogen react with unsaturated fatty acids, such as conjugated linoleic acid, to form nitroalkenes, and these have been shown to inhibit proinflammatory cytokines, such as endothelial TNF- $\alpha$ [92].

The association between processed meat and CRC is more pronounced in those studies considering only nitrite-containing processed meats. However, the relationship still remains modest in comparison to established carcinogens, such as smoking, that exhibit relative risks in excess of 100 fold [93]. Many of the human studies supporting a role for processed meat in colorectal cancer pathogenesis suffer from methodological limitations. Conversely, the preclinical studies are well controlled, yet yield conflicting results. Preclinical studies indicate that that low processed-meat-consumption does not increase CRC risk; however, high consumption does. It is reported that NOC levels are higher in the faeces of rodents consuming nitrite than in controls [17]; however, this increase does not result in an increased incidence 
of adenomas, and that is because not all NOCs are carcinogenic [94]. An unintended consequence of the addition of sodium nitrite to meat is the interaction with secondary amines and the formation of NOCs; a wide range of NOCs exist and the individual risk of each is yet to be characterised. It is possible that the discordance in results is explained by a diverse range of NOCs being formed in each preclinical study.

The use of nitrites as curing agents is controversial. The findings summarised in this review raise more concerns with its usage. It has been reported that the removal of nitrite from processed meat does not compromise its safety [95]; this issue has attracted considerable media attention [96]. It is clear that well-designed, peer-reviewed research that investigates the efficacy of sodium nitrite as a preservative is needed.

Future epidemiological studies should consider more specifically categorising the processed meat consumed, explicitly distinguishing between those meats which are nitrite-containing and those which are not. When this type of data becomes available it will be possible to infer the actual risk posed by the addition of nitrites. Furthermore, preclinical dose response studies are currently lacking and these could help refine the no observed adverse effect level (NOAEL), informing the design of human intervention studies. On the basis of several observational studies [32,34,57,74], the WHO has declared that processed meat should be avoided entirely. Currently, all processed meats are considered group 1 carcinogens, despite there being a vast difference in nutrient compositions. Some processed meats do not contain nitrite; therefore, it is possible that not all processed meats carry the same level of risk.

Supplementary Materials: The following are available online at http://www.mdpi.com/2072-6643/11/11/2673/s1: Table S1: Characteristics of prospective human studies assessing colorectal cancer and processed meat consumption; Table S2: Characteristics of case control human studies assessing colorectal cancer and processed meat consumption.

Author Contributions: W.C. conducted the literature searches and composed the tables. W.C. also contributed to the manuscript along with C.T.E. and B.D.G.

Funding: Studies investigating links between meat consumption and CRC are in part supported by Agri-Food QUEST, a membership-based, industry-led Innovation Centre for agri-food business in Northern Ireland. Agri-Food QUEST is supported by funding from Invest Northern Ireland.

Conflicts of Interest: A currently-held Agri-Food Quest project is partially supported by commercial funding from: Finnebrogue Artisan, Karro Food group, and Cranswick. Industrial partners were not involved design or writing of the manuscript, the analysis/interpretation of the data, or the decision to publish.

\section{References}

1. IARC Working group. Monographs on the Evaluation of Carcinogenic Risks to Humans; The Lancet Oncology: London, UK, 2018.

2. World Cancer Research Fund. Food, Nutrition, Physical Activity, and the Prevention of Cancer: A Global Perspective; Choice: Current Reviews for Academic Libraries: Middletown, CT, USA, 2007.

3. World Cancer Research Fund. Diet, Nutrition, Physical Activity and Cancer: A Global Perspective; American Institute for Cancer Research: Arlington, VA, USA, 2018.

4. Bouvard, V.; Loomis, D.; Guyton, K.Z.; Grosse, Y.; El Ghissassi, F.; Benbrahim-Tallaa, L.; Guha, N.; Mattock, H.; Straif, K. Carcinogenicity of consumption of red and processed meat. Lancet Oncol. 2015, 16, 1599-1600. [CrossRef]

5. Larsson, S.C.; Wolk, A. Meat consumption and risk of colorectal cancer: A meta-analysis of prospective studies. Int. J. Cancer 2006, 119, 2657-2664. [CrossRef]

6. Huxley, R.R.; Clifton, P.; Czernichow, S.; Parr, C.L.; Woodward, M.; Ansary-Moghaddam, A.; Ansary-Moghaddam, A. The impact of dietary and lifestyle risk factors on risk of colorectal cancer: A quantitative overview of the epidemiological evidence. Int. J. Cancer 2009, 125, 171-180. [CrossRef]

7. Alexander, D.D.; Miller, A.J.; Cushing, C.A.; Lowe, K.A. Processed meat and colorectal cancer: A quantitative review of prospective epidemiologic studies. Eur. J. Cancer Prev. 2010, 19, 328-341. [CrossRef] [PubMed]

8. Chan, D.S.M.; Lau, R.; Aune, D.; Vieira, R.; Greenwood, D.C.; Kampman, E.; Norat, T. Red and Processed Meat and Colorectal Cancer Incidence: Meta-Analysis of Prospective Studies. PLoS ONE 2011, 6, e20456. [CrossRef] 
9. Hutter, C.M.; Chang-Claude, J.; Slattery, M.L.; Pflugeisen, B.M.; Lin, Y.; Duggan, D.; Nan, H.; Lemire, M.; Rangrej, J.; Figueiredo, J.C.; et al. Characterization of gene-environment interactions for colorectal cancer susceptibility loci. Cancer Res. 2012, 72, 2036-2044. [CrossRef] [PubMed]

10. Pham, N.M.; Sasazuki, S.; Tsugane, S.; Inoue, M.; Iwasaki, M.; Otani, T.; Sawada, N.; Shimazu, T.; Yamaji, T.; Tsuji, I.; et al. Meat Consumption and Colorectal Cancer Risk: An Evaluation Based on a Systematic Review of Epidemiologic Evidence Among the Japanese Population. Jpn. J. Clin. Oncol. 2014, 44, 641-650. [CrossRef] [PubMed]

11. Zhu, H.; Yang, X.; Zhang, C.; Zhu, C.; Tao, G.; Zhao, L.; Tang, S.; Shu, Z.; Cai, J.; Dai, S.; et al. Red and Processed Meat Intake Is Associated with Higher Gastric Cancer Risk: A Meta-Analysis of Epidemiological Observational Studies. PLoS ONE 2013, 8, e70955. [CrossRef]

12. Johnson, C.M.; Wei, C.; Ensor, J.E.; Smolenski, D.J.; Amos, C.I.; Levin, B.; Berry, D.A. Meta-analyses of colorectal cancer risk factors. Cancer Causes Control 2013, 24, 1207-1222. [CrossRef]

13. Parkin, D.; Khlat, M. Studies of cancer in migrants: Rationale and methodology. Eur. J. Cancer 1996, 32, 761-771. [CrossRef]

14. Santarelli, R.L.; Pierre, F.; Corpet, D.E. Processed meat and colorectal cancer: A review of epidemiologic and experimental evidence. Nutr. Cancer 2008, 60, 131-144. [CrossRef]

15. De Mey, E.; de Maere, H.; Paelinck, H.; Fraeye, I. Volatile N-nitrosamines in meat products: Potential precursors, influence of processing, and mitigation strategies. Crit. Rev. Food Sci. Nutr. 2017, 57, 2909-2923. [CrossRef] [PubMed]

16. Chenni, F.Z.; Taché, S.; Naud, N.; Guéraud, F.; Hobbs, D.A.; Kunhle, G.G.C.; Pierre, F.H.; Corpet, D.E. Heme-induced biomarkers associated with red meat promotion of colon cancer are not modulated by the intake of nitrite. Nutr. Cancer 2013, 65, 227-233. [CrossRef] [PubMed]

17. Parnaud, G.; Peiffer, G.; Taché, S.; Corpet, D.E. Effect of meat (beef, chicken, and bacon) on rat colon carcinogenesis. Nutr. Cancer 1998, 32, 165-173. [CrossRef] [PubMed]

18. Bastide, N.M.; Chenni, F.; Audebert, M.; Santarelli, R.L.; Naud, N.; Baradat, M.; Jouanin, I.; Surya, R.; Hobbs, D.A.; Kuhnle, G.; et al. A Central Role for Heme Iron in Colon Carcinogenesis Associated with Red Meat Intake. Cancer Res. 2015, 75, 870-879. [CrossRef] [PubMed]

19. Zhou, L.; Zahid, M.; Anwar, M.M.; Pennington, K.L.; Cohen, S.M.; Wisecarver, J.L.; Shostrom, V.; Mirvish, S.S. Suggestive evidence for the induction of colonic aberrant crypts in mice fed sodium nitrite. Nutr. Cancer 2015, 68, 105-112. [CrossRef]

20. Santarelli, R.L.; Vendeuvre, J.-L.; Naud, N.; Taché, S.; Guéraud, F.; Viau, M.; Genot, C.; Corpet, D.E.; Pierre, F.H. Meat processing and colon carcinogenesis: Cooked, nitrite-treated, and oxidized high-heme cured meat promotes mucin-depleted foci in rats. Cancer Prev. Res. 2010, 3, 852-864. [CrossRef]

21. Santarelli, R.L.; Naud, N.; Taché, S.; Guéraud, F.; Vendeuvre, J.-L.; Zhou, L.; Anwar, M.M.; Mirvish, S.S.; Corpet, D.E.; Pierre, F.H. Calcium inhibits promotion by hot dog of 1,2-dimethylhydrazine-induced mucin-depleted foci in rat colon. Int. J. Cancer 2013, 133, 2533-2541. [CrossRef]

22. Pierre, F.H.; Martin, O.C.; Santarelli, R.L.; Taché, S.; Naud, N.; Guéraud, F.; Audebert, M.; Dupuy, J.; Meunier, N.; Attaix, D.; et al. Calcium and $\alpha$-tocopherol suppress cured-meat promotion of chemically induced colon carcinogenesis in rats and reduce associated biomarkers in human volunteers. Am. J. Clin. Nutr. 2013, 98, 1255-1262. [CrossRef]

23. Bastide, N.M.; Naud, N.; Nassy, G.; Vendeuvre, J.-L.; Taché, S.; Guéraud, F.; Hobbs, D.A.; Kuhnle, G.G.; Corpet, D.E.; Pierre, F.H.F. Red Wine and Pomegranate Extracts Suppress Cured Meat Promotion of Colonic Mucin-Depleted Foci in Carcinogen-Induced Rats. Nutr. Cancer 2017, 69, 289-298. [CrossRef]

24. Pierre, F.H.F.; Santarelli, R.L.; Allam, O.; Taché, S.; Naud, N.; Guéraud, F.; Corpet, D.E.; Chartron, M. Freeze-dried ham promotes azoxymethane-induced mucin-depleted foci and aberrant crypt foci in rat colon. Nutr. Cancer 2010, 62, 567-573. [CrossRef]

25. Mirvish, S.S.; Haorah, J.; Zhou, L.; Hartman, M.; Morris, C.R.; Clapper, M.L. N-nitroso compounds in the gastrointestinal tract of rats and in the feces of mice with induced colitis or fed hot dogs or beef. Carcinogenesis 2003, 24, 595-603. [CrossRef] [PubMed]

26. Parnaud, G.; Pignatelli, B.; Peiffer, G.; Taché, S.; Corpet, D.E. Endogenous N-Nitroso Compounds, and Their Precursors, Present in Bacon, Do Not Initiate or Promote Aberrant Crypt Foci in the Colon of Rats. Nutr. Cancer 2000, 38, 74-80. [CrossRef] [PubMed] 
27. Cross, A.J.; Pollock, J.R.A.; Bingham, S.A. Haem, not protein or inorganic iron, is responsible for endogenous intestinal N-nitrosation arising from red meat. Cancer Res. 2003, 63, 2358-2360.

28. Corpet, D.E.; Taché, S. Most effective colon cancer chemopreventive agents in rats: A systematic review of aberrant crypt foci and tumor data, ranked by potency. Nutr. Cancer 2002, 43, 1-21. [CrossRef] [PubMed]

29. Femia, A.P.; Dolara, P.; Caderni, G. Mucin-depleted foci (MDF) in the colon of rats treated with azoxymethane (AOM) are useful biomarkers for colon carcinogenesis. Carcinogenesis 2004, 25, 277-281. [CrossRef] [PubMed]

30. Liu, Y.; Yin, T.; Feng, Y.; Cona, M.M.; Huang, G.; Liu, J.; Song, S.; Jiang, Y.; Xia, Q.; Swinnen, J.V.; et al. Mammalian models of chemically induced primary malignancies exploitable for imaging-based preclinical theragnostic research. Quant. Imaging Med. Surg. 2015, 5, 708-729.

31. Calmels, S.; Béréziat, J.C.; Ohshima, H.; Bartsch, H. Bacterial formation of N-nitroso compounds from administered precursors in the rat stomach after omeprazole-induced achlorhydria. Carcinogenesis 1991, 12, 435-439. [CrossRef]

32. Oba, S.; Shimizu, N.; Nagata, C.; Shimizu, H.; Kametani, M.; Takeyama, N.; Ohnuma, T.; Matsushita, S. The relationship between the consumption of meat, fat, and coffee and the risk of colon cancer: A prospective study in Japan. Cancer Lett. 2006, 244, 260-267. [CrossRef]

33. Goldbohm, R.A.; Brandt, P.A.V.D.; van't Veer, P.; Brants, H.A.; Dorant, E.; Sturmans, F.; Hermus, R.J. A prospective cohort study on the relation between meat consumption and the risk of colon cancer. Cancer Res. 1994, 54, 718-723.

34. Tajima, K.; Tominaga, S. [A comparative case-control study of stomach and large intestinal cancers]. Gan No Rinsho. Jpn. J. Cancer Clin. 1986, 32, 705-716.

35. Levi, F.; Pasche, C.; Lucchini, F.; Bosetti, C.; La Vecchia, C. Processed meat and the risk of selected digestive tract and laryngeal neoplasms in Switzerland. Ann. Oncol. 2004, 15, 346-349. [CrossRef] [PubMed]

36. Haenszel, W.; Segi, M.; Kurihara, M.; Locke, F.B.; Berg, J.W. Large-Bowel Cancer in Hawaiian Japanese2. J. Natl. Cancer Inst. 1973, 51, 1765-1779. [CrossRef]

37. Young, T.B.; Wolf, D.A. Case-control study of proximal and distal colon cancer and diet in Wisconsin. Int. J. Cancer 1988, 42, 167-175. [CrossRef] [PubMed]

38. Bidoli, E.; Franceschi, S.; Talamini, R.; Barra, S.; La Vecchia, C. Food consumption and cancer of the colon and rectum in north-eastern Italy. Int. J. Cancer 1992, 50, 223-229. [CrossRef] [PubMed]

39. Navarro, A.; Díaz, M.P.; Muñoz, S.E.; Lantieri, M.J.; Eynard, A.R. Characterization of meat consumption and risk of colorectal cancer in Cordoba, Argentina. Nutrition 2003, 19, 7-10. [CrossRef]

40. Rosato, V.; Bosetti, C.; Levi, F.; Polesel, J.; Zucchetto, A.; Negri, E.; La Vecchia, C. Risk factors for young-onset colorectal cancer. Cancer Causes Control 2013, 24, 335-341. [CrossRef]

41. Hu, J.; La Vecchia, C.; Desmeules, M.; Negri, E.; Mery, L.; Epidemio, C.C.R. Meat and Fish Consumption and Cancer in Canada. Nutr. Cancer 2008, 60, 313-324. [CrossRef]

42. De Verdier, M.G.; Hagman, U.; Peters, R.K.; Steineck, G.; Övervik, E. Meat, cooking methods and colorectal cancer: A case-referent study in Stockholm. Int. J. Cancer 1991, 49, 520-525. [CrossRef]

43. Macquart-Moulin, G.; Riboli, E.; Cornée, J.; Charnay, B.; Berthezene, P.; Day, N. Case-control study on colorectal cancer and diet in marseilles. Int. J. Cancer 1986, 38, 183-191. [CrossRef]

44. Parr, C.L.; Hjartåker, A.; Lund, E.; Veierød, M.B. Meat intake, cooking methods and risk of proximal colon, distal colon and rectal cancer: The Norwegian Women and Cancer (NOWAC) cohort study. Int. J. Cancer 2013, 133, 1153-1163. [CrossRef] [PubMed]

45. Nowell, S.; Coles, B.; Sinha, R.; MacLeod, S.; Ratnasinghe, D.L.; Stotts, C.; Kadlubar, F.F.; Ambrosone, C.B.; Lang, N.P. Analysis of total meat intake and exposure to individual heterocyclic amines in a case-control study of colorectal cancer: Contribution of metabolic variation to risk. Mutat. Res. Mol. Mech. Mutagen. 2002, 506, 175-185. [CrossRef]

46. Bradbury, K.E.; Murphy, N.; Key, T.J. Diet and colorectal cancer in UK Biobank: A prospective study. Int. J. Epidemiol. 2019. [CrossRef] [PubMed]

47. Cross, A.J.; Ferrucci, L.M.; Risch, A.; Graubard, B.I.; Ward, M.H.; Park, Y.; Hollenbeck, A.R.; Schatzkin, A.; Sinha, R. A Large Prospective Study of Meat Consumption and Colorectal Cancer Risk: An Investigation of Potential Mechanisms Underlying this Association. Cancer Res. 2010, 70, 2406-2414. [CrossRef] [PubMed]

48. Wu, K.; Giovannucci, E.; Byrne, C.; Platz, E.A.; Fuchs, C.; Willett, W.C.; Sinha, R. Meat Mutagens and Risk of Distal Colon Adenoma in a Cohort of U.S. Men. Cancer Epidemiol. Biomark. Prev. 2006, 15, 1120-1125. [CrossRef] [PubMed] 
49. English, D.R.; MacInnis, R.J.; Hodge, A.M.; Hopper, J.L.; Haydon, A.M.; Giles, G.G. Red meat, chicken, and fish consumption and risk of colorectal cancer. Cancer Epidemiol. Biomark. Prev. 2004, 13, 1509-1515.

50. Norat, T.; Bingham, S.; Riboli, E. RESPONSE: Re: Meat, Fish, and Colorectal Cancer Risk: The European Prospective Investigation into Cancer and Nutrition. J. Natl. Cancer Inst. 2005, 97, 1788-1789. [CrossRef]

51. Willett, W.C.; Stampfer, M.J.; Colditz, G.A.; Rosner, B.A.; Speizer, F.E. Relation of Meat, Fat, and Fiber Intake to the Risk of Colon Cancer in a Prospective Study among Women. N. Engl. J. Med. 1990, 323, 1664-1672. [CrossRef]

52. Cross, A.J.; Leitzmann, M.F.; Gail, M.H.; Hollenbeck, A.R.; Schatzkin, A.; Sinha, R. A prospective study of red and processed meat intake in relation to cancer risk. PLoS Med. 2007, 4, e325. [CrossRef]

53. Lohsoonthorn, P.; Danvivat, D. Colorectal Cancer Risk Factors: A Case-control Study in Bangkok. Asia Pac. J. Public Health 1995, 8, 118-122. [CrossRef]

54. De Stefani, E.; Boffetta, P.; Ronco, A.L.; Deneo-Pellegrini, H.; Correa, P.; Acosta, G.; Mendilaharsu, M.; Luaces, M.E.; Silva, C. Processed meat consumption and risk of cancer: A multisite case-control study in Uruguay. Br. J. Cancer 2012, 107, 1584-1588. [CrossRef]

55. Bostick, R.M.; Potter, J.D.; Kushi, L.H.; Sellers, T.A.; Steinmetz, K.A.; McKenzie, D.R.; Gapstur, S.M.; Folsom, A.R. Sugar, meat, and fat intake, and non-dietary risk factors for colon cancer incidence in Iowa women (United States). Cancer Causes Control 1994, 5, 38-52. [CrossRef]

56. Takachi, R.; Tsubono, Y.; Baba, K.; Inoue, M.; Sasazuki, S.; Iwasaki, M.; Tsugane, S.; Japan Public Health Center-based Prospective Study Group. Red meat intake may increase the risk of colon cancer in Japanese, a population with relatively low red meat consumption. Asia Pac. J. Clin. Nutr. 2011, 20, 603-612. [PubMed]

57. Sato, Y.; Nakaya, N.; Kuriyama, S.; Nishino, Y.; Tsubono, Y.; Tsuji, I. Meat consumption and risk of colorectal cancer in Japan: The Miyagi Cohort Study. Eur. J. Cancer Prev. 2006, 15, 211-218. [CrossRef] [PubMed]

58. Lin, J.; Zhang, S.M.; Cook, N.R.; Lee, I.-M.; Buring, J.E. Dietary Fat and Fatty Acids and Risk of Colorectal Cancer in Women. Am. J. Epidemiol. 2004, 160, 1011-1022. [CrossRef] [PubMed]

59. Knekt, P.; Dich, J.; Hakulinen, T.; Järvinen, R. Risk of colorectal and other gastro-intestinal cancers after exposure to nitrate, nitrite and N-nitroso compounds: A follow-up study. Int. J. Cancer 1999, 80, 852-856. [CrossRef]

60. Williams, C.D.; Satia, J.A.; Adair, L.S.; Stevens, J.; Galanko, J.; Keku, T.O.; Sandler, R.S. Associations of red meat, fat, and protein intake with distal colorectal cancer risk. Nutr. Cancer 2010, 62, 701-709. [CrossRef]

61. Benito, E.; Obrador, A.; Stiggelbout, A.; Bosch, F.X.; Mulet, M.; Munoz, N.; Kaldor, J. A population-based case-control study of colorectal cancer in Majorca. I. Dietary factors. Int. J. Cancer 1990, 45, 69-76. [CrossRef]

62. Dales, L.G.; Friendman, G.D.; Ury, H.K.; Grossman, S.; Williams, S.R. A case control study of relationships of diet and other traits to colorectal cancer in American blacks. Am. J. Epidemiol. 1978, 109, 132-145. [CrossRef]

63. Joshi, A.D.; Kim, A.; Lewinger, J.P.; Ulrich, C.M.; Potter, J.D.; Cotterchio, M.; Le Marchand, L.; Stern, M.C. Meat intake, cooking methods, dietary carcinogens, and colorectal cancer risk: Findings from the Colorectal Cancer Family Registry. Cancer Med. 2015, 4, 936-952. [CrossRef]

64. Balder, H.F.; Vogel, J.; Jansen, M.C.; Weijenberg, M.P.; Westenbrink, S.; Van Der Meer, R.; Goldbohm, R.A.; Brandt, P.A.V.D. Heme and Chlorophyll Intake and Risk of Colorectal Cancer in the Netherlands Cohort Study. Cancer Epidemiol. Biomark. Prev. 2006, 15, 717-725. [CrossRef] [PubMed]

65. Murtaugh, M.A.; Ma, K.-N.; Sweeney, C.; Caan, B.J.; Slattery, M.L. Meat consumption patterns and preparation, genetic variants of metabolic enzymes, and their association with rectal cancer in men and women. J. Nutr. 2004, 134, 776-784. [CrossRef] [PubMed]

66. Kimura, Y.; Kono, S.; Toyomura, K.; Nagano, J.; Mizoue, T.; Moore, M.A.; Mibu, R.; Tanaka, M.; Kakeji, Y.; Maehara, Y.; et al. Meat, fish and fat intake in relation to subsite-specific risk of colorectal cancer: The Fukuoka Colorectal Cancer Study. Cancer Sci. 2007, 98, 590-597. [CrossRef] [PubMed]

67. Pietinen, P.; Malila, N.; Virtanen, M.; Hartman, T.J.; Tangrea, J.A.; Albanes, D.; Virtamo, J. Diet and risk of colorectal cancer in a cohort of Finnish men. Cancer Causes Control 1999, 10, 387-396. [CrossRef] [PubMed]

68. Nöthlings, U.; Yamamoto, J.F.; Wilkens, L.R.; Murphy, S.P.; Park, S.-Y.; Henderson, B.E.; Kolonel, L.N.; Le Marchand, L. Meat and heterocyclic amine intake, smoking, NAT1 and NAT2 polymorphisms, and colorectal cancer risk in the multiethnic cohort study. Cancer Epidemiol. Biomark. Prev. 2009, 18, 2098-2106. [CrossRef] [PubMed]

69. Steinmetz, K.A.; Potter, J.D. Food-group consumption and colon cancer in the adelaide case-control study. II. Meat, poultry, seafood, dairy foods and eggs. Int. J. Cancer 1993, 53, 720-727. [CrossRef] 
70. Franceschi, S.; Favero, A.; La Vecchia, C.; Negri, E.; Conti, E.; Montella, M.; Giacosa, A.; Nanni, O.; DeCarli, A. Food groups and risk of colorectal cancer in Italy. Int. J. Cancer 1997, 72, 56-61. [CrossRef]

71. Centonze, S.; Boeing, H.; Leoci, C.; Guerra, V.; Misciagna, G. Dietary habits and colorectal cancer in a low-risk area. Results from a population-based case-control study in southern Italy. Nutr. Cancer 1994, 21, 233-246. [CrossRef]

72. Tiemersma, E.W.; Kampman, E.; De Mesquita, H.B.B.; Bunschoten, A.; Van Schothorst, E.M.; Kok, F.J.; Kromhout, D. Meat consumption, cigarette smoking, and genetic susceptibility in the etiology of colorectal cancer: Results from a Dutch prospective study. Cancer Causes Control 2002, 13, 383-393. [CrossRef]

73. Giovannucci, E.; Rimm, E.B.; Stampfer, M.J.; Colditz, G.A.; Ascherio, A.; Willett, W.C. Intake of fat, meat, and fiber in relation to risk of colon cancer in men. Cancer Res. 1994, 54, 2390-2397.

74. Chao, A. Meat Consumption and Risk of Colorectal Cancer. JAMA 2005, 293, 172. [CrossRef] [PubMed]

75. Lee, S.-A.; Shu, X.O.; Yang, G.; Li, H.; Gao, Y.-T.; Zheng, W. Animal origin foods and colorectal cancer risk: A report from the Shanghai Women's Health Study. Nutr. Cancer 2009, 61, 194-205. [CrossRef] [PubMed]

76. Larsson, S.C.; Rafter, J.; Holmberg, L.; Bergkvist, L.; Wolk, A. Red meat consumption and risk of cancers of the proximal colon, distal colon and rectum: The Swedish Mammography Cohort. Int. J. Cancer 2005, 113, 829-834. [CrossRef] [PubMed]

77. Ollberding, N.J.; Wilkens, L.R.; Henderson, B.E.; Kolonel, L.N.; Le Marchand, L. Meat consumption, heterocyclic amines and colorectal cancer risk: The Multiethnic Cohort Study. Int. J. Cancer 2012, 131, E1125-E1133. [CrossRef] [PubMed]

78. Egeberg, R.; Olsen, A.; Christensen, J.; Halkjær, J.; Jakobsen, M.U.; Overvad, K.; Tjønneland, A. Associations between Red Meat and Risks for Colon and Rectal Cancer Depend on the Type of Red Meat Consumed. J. Nutr. 2013, 143, 464-472. [CrossRef]

79. Flood, A.; Velie, E.M.; Sinha, R.; Chaterjee, N.; Lacey, J.V., Jr.; Schairer, C.; Schatzkin, A. Meat, Fat, and Their Subtypes as Risk Factors for Colorectal Cancer in a Prospective Cohort of Women. Am. J. Epidemiol. 2003, 158, 59-68. [CrossRef] [PubMed]

80. Iscovich, J.M.; L'Abbé, K.A.; Castelleto, R.; Calzona, A.; Bernedo, A.; Chopita, N.A.; Jmelnitzsky, A.C.; Kaldor, J. Colon cancer in Argentina. I: Risk from intake of dietary items. Int. J. Cancer 1992, 51, 851-857. [CrossRef] [PubMed]

81. Armstrong, B.; Doll, R. Environmental factors and cancer incidence and mortality in different countries, with special reference to dietary practices. Int. J. Cancer 1975, 15, 617-631. [CrossRef]

82. Tricker, A. N-nitroso compounds and man: Sources of exposure, endogenous formation and occurrence in body fluids. Eur. J. Cancer Prev. 1997, 6, 226-268. [CrossRef]

83. Veena, S.; Rashmi, S. A review on mechanism of nitrosamine formation, metabolism and toxicity in in vivo. Int. J. Toxicol. Pharmacol. Res. 2014, 6, 86-96.

84. International Agency for Research on Cancer. Evaluation of carcinogenic risks Overall Evaluations of Carcinogenicity; IARC Monographs: Lyon, France, 1987.

85. Fahrer, J.; Kaina, B. Review O 6-methylguanine-DNA methyltransferase in the defense against N-nitroso compounds and colorectal cancer. Carcinogenesis 2013, 34, 2435-2442. [CrossRef] [PubMed]

86. Beranek, D.T. Distribution of methyl and ethyl adducts following alkylation with monofunctional alkylating agents. Mutat. Res. Mol. Mech. Mutagen. 1990, 231, 11-30. [CrossRef]

87. Kamataki, T.; Fujita, K.-I.; Nakayama, K.; Yamazaki, Y.; Miyamoto, M.; Ariyoshi, N. Role of human cytochrome p450 (CYP) in the metabolic activation of nitrosamine derivatives: Application of genetically engineered salmonella expressing human CYP. Drug Metab. Rev. 2002, 34, 667-676. [CrossRef] [PubMed]

88. Kuhnle, G.G.; Story, G.W.; Reda, T.; Mani, A.R.; Moore, K.P.; Lunn, J.C.; Bingham, S.A. Diet-induced endogenous formation of nitroso compounds in the GI tract. Free. Radic. Boil. Med. 2007, 43, 1040-1047. [CrossRef]

89. McCullough, M.L.; Gapstur, S.M.; Shah, R.; Jacobs, E.J.; Campbell, P.T. Association between red and processed meat intake and mortality among colorectal cancer survivors. J. Clin. Oncol. 2013, 31, 2773-2782. [CrossRef]

90. Fogelholm, M.; Kanerva, N.; Männistö, S. Association between red and processed meat consumption and chronic diseases: The confounding role of other dietary factors. Eur. J. Clin. Nutr. 2015, 69, 1060-1065. [CrossRef] 
91. Dykhuizen, R.S.; Frazer, R.; Duncan, C.; Smith, C.C.; Golden, M.; Benjamin, N.; Leifert, C. Antimicrobial effect of acidified nitrite on gut pathogens: Importance of dietary nitrate in host defense. Antimicrob. Agents Chemother. 1996, 40, 1422-1425. [CrossRef]

92. Cui, T.; Schopfer, F.J.; Zhang, J.; Chen, K.; Ichikawa, T.; Baker, P.R.S.; Batthyany, C.; Chacko, B.K.; Feng, X.; Patel, R.P.; et al. Nitrated fatty acids: Endogenous anti-inflammatory signaling mediators. J. Boil. Chem. 2006, 281, 35686-35698. [CrossRef]

93. Pesch, B.; Kendzia, B.; Gustavsson, P.; Jöckel, K.H.; Johnen, G.; Pohlabeln, H.; Olsson, A.; Ahrens, W.; Gross, I.M.; Brüske, I.; et al. Cigarette smoking and lung cancer-Relative risk estimates for the major histological types from a pooled analysis of case-control studies. Int. J. Cancer 2012, 131, 1210-1219. [CrossRef]

94. Lijinsky, W. N-Nitroso compounds in the diet. Mutat. Res. Genet. Toxicol. Environ. Mutagen. 1999, 443, 129-138. [CrossRef]

95. Hospital, X.F.; Hierro, E.; Stringer, S.; Fernández, M. International Journal of Food Microbiology A study on the toxigenesis by Clostridium botulinum in nitrate and nitrite-reduced dry fermented sausages. Int. J. Food Microbiol. 2016, 218, 66-70. [CrossRef] [PubMed]

96. The Guardian. Revealed: No Need to Add Cancer Risk Nitrites to Ham. Available online: https://www.theguardian.com/food/2019/mar/23/nitrites-ham-bacon-cancer-risk-additives-meatindustry-confidential--report (accessed on 17 October 2019).

(C) 2019 by the authors. Licensee MDPI, Basel, Switzerland. This article is an open access article distributed under the terms and conditions of the Creative Commons Attribution (CC BY) license (http://creativecommons.org/licenses/by/4.0/). 